\title{
LncRNA SNHGI6 Regulates the Progress of Acute Myeloid Leukemia Through miRI83-5p-FOXOI Axis [Retraction]
}

Yang R, Ma D, Wu Y, Zhang Y, Zhang L. Onco Targets Ther. 2020;13:12943-12954.

At the authors request, the Editor and Publisher of OncoTargets and Therapy wish to retract the published article. The authors informed the journal that when attempting to reproduce the induction of THP-1 cells to differentiate into macrophages, it was found the THP-1 cells were still suspended, with few adhering cells and no pseudopodia or other macrophage cell forms. The cells were subsequently collected for flow analysis, and no markers of macrophages could be detected. The authors believe that the cell line used for the original experiments was contaminated. In addition, the authors have informed the journal that they cannot provide the original raw data for the reported study. As a result, the authors have determined the findings of the study are invalid and requested for the article to be retracted.

The authors wish to apologise for this error.

Our decision-making was informed by our policy on publishing ethics and integrity and the COPE guidelines on retraction.

The retracted article will remain online to maintain the scholarly record, but it will be digitally watermarked on each page as "Retracted".

\section{Publish your work in this journal}

OncoTargets and Therapy is an international, peer-reviewed, open access journal focusing on the pathological basis of all cancers, potential targets for therapy and treatment protocols employed to improve the management of cancer patients. The journal also focuses on the impact of management programs and new therapeutic agents and protocols on patient perspectives such as quality of life, adherence and satisfaction. The manuscript management system is completely online and includes a very quick and fair peer-review system, which is all easy to use. Visit http://www.dovepress.com/ testimonials.php to read real quotes from published authors. 